\title{
Zróżnicowanie opóźnień płatniczych w przedsiębiorstwach sektora B2B krajów Europy Wschodniej
}

\section{DIFFERENTIATION OF PAYMENT DELAYS IN THE B2B SECTOR ENTERPRISES IN EASTERN EUROPE}

W artykule przedstawiono wyniki wieloaspektowej analizy zróżnicowania terminów płatności w transakcjach handlowych między przedsiębiorstwami sektora B2B w wybranych krajach Europy Wschodniej. Analizę oparto na danych pochodzących z raportów międzynarodowej wywiadowni gospodarczej Atriadus dotyczących przedsiębiorstw w Polsce, Słowacji, Czechach, na Wegrzech oraz w Turcji. Badania wykazały, że średnio około $41 \%$ sprzedaży w badanych przedsiębiorstw sektora B2B Europy Wschodniej realizowano przy zastosowaniu kredytu kupieckiego, w tym głównie w transakcjach zagranicznych, a kontrakty zawierano głównie na termin do 30 dni (ponad $80 \%$ ), poza Turcja gdzie należności zakontraktowane stanowiły około $54 \%$ umów. Ponadto stwierdzono, że najmniejsze opóźnienia płatności cechowały przedsiębiorstwa na Słowacji i Węgrzech (10-17 dni), natomiast największe w Turcji (76 dni). Z badań wynika również, że główne przyczyny opóźnień płatniczych przedsiębiorcy $\mathrm{z}$ sektora $\mathrm{B} 2 \mathrm{~B}$ upatrują $\mathrm{w}$ ograniczonym dostępie kontrahentów do środków finansowych, w praktyce traktowania zaległych zobowiązań jako źródła finansowania bieżącej działalności, formalnej niewypłacalności kontrahentów oraz w złożonych procedurach płatności.

Słowa kluczowe: opóźnienia płatnicze, sektor B2B, Europa Wschodnia

\section{Wstęp}

Kryzys finansowy, który wystąpił pod koniec 2008 roku, spowodował znaczące osłabienie dynamiki gospodarczej i pogorszenie kondycji finansowej przedsiębiorstw. Jednak niestabilna koniunktura związana ze słabą dynamiką wygaszania kryzysu finansowego nadal negatywnie oddziałuje na dynamikę gospodarczą oraz sytuację finansową przedsiębiorstw. Intensywność występowania problemów $\mathrm{z}$ terminowym regulowaniem zobowiązań wprawdzie maleje, ale tempo zmian w tym zakresie jest na tyle słabe ${ }^{1}$, że pogorszenie płynności finansowej i związane $\mathrm{z}$ nim zjawiska wzrostu

\footnotetext{
1 Gołaś J.: Prawne i ekonomiczne uwarunkowania opóźnień płatniczych w transakcjach handlowych przedsiębiorstw w Polsce, Ekonomika i Organizacja Przedsiębiorstw, nr 2/2016.
} 
kosztów, strat ${ }^{2}$ oraz redukcji przychodów i zysków dotyczą wciąż dużej liczby podmiotów gospodarczych.

Problem nieterminowego regulowania zobowiązań przyczynia się do powstawania zatorów płatniczych, tj. kumulacji długów i ich przechodzenie na kolejnych powiązanych ze sobą kontrahentów ${ }^{3}$, co w skrajnym przypadku mogą prowadzić do upadłości przedsiębiorstw ${ }^{4,5}$.

Duża skala problemów płatniczych europejskich przedsiębiorstw przyczyniła się do prawnej regulacji terminów płatności w transakcjach handlowych między organami publicznymi i przedsiębiorstwami oraz między przedsiębiorstwami. Wyrazem tej regulacji jest Dyrektywa Parlamentu Europejskiego i Rady z 2011 roku ${ }^{6}$ oraz obowiązkowa jej transpozycja na kraje członkowskie do marca 2013 roku. Jednak aktualne statystyki wskazują wyraźnie, że postęp w zakresie opóźnień płatniczych jest generalnie w krajach europejskich bardzo słaby, a w znacznej ich części problem opóźnień płatniczych narasta.

\section{Cel i metodyka badań oraz material źródłowy}

Głównym celem opracowania jest wieloaspektowa ocena zróżnicowania terminów płatności w transakcjach handlowych między przedsiębiorstwami sektora B2B w wybranych krajach Europy Wschodniej. W realizacji tak sformułowanego celu wykorzystano informacje dotyczące skłonności do udzielania kredytu kupieckiego, struktury czasowej należności zakontraktowanych i przeterminowanych, długości zakontraktowanego i faktycznego terminu płatności, czasu opóźnienia płatności, odsetka płatności przeterminowanych i nieściagalnych oraz przyczyn opóźnienia płatności.

Dane do analizy pochodziły z raportów firmy Atriadus, znaczącego na rynku europejskim podmiotu rynku ubezpieczeń finansowych i windykacji. Głównym obszarem działalności tej firmy są ubezpieczenia kredytu kupieckiego oraz usługi windykacyjne, a jej jednym z ważnych celów jest wzmacnianie polityki zarządzania należnościami klientów ${ }^{7}$. Analizę zróżnicowania i uwarunkowań opóźnień płatniczych przeprowadzono na podstawie danych z 2015 roku publikowanych w specjalistycznych raportach - Barometr Praktyk Płatniczych - dotyczących wybranych krajów Europy

\footnotetext{
${ }^{2}$ Według wywiadowni gospodarczej Intrum Justitia w 2015 roku straty przedsiębiorstw z tytułu utraconych należności wynosiły od 1,0\% w Dani do 10,4\% wartości przychodów, przy średniej na poziomie około 3,1\%. Łączne straty w Europie z tego tytułu szacuje się na kwotę 289 mld euro [European ...2015].

${ }^{3}$ Cicirko T.: Możliwości ograniczania zatorów płatniczych poprzez system podatkowy. Zeszyty Naukowe Politechniki Rzeszowskiej, Zarządzanie i Marketing, nr 272(17)/2010.

${ }^{4}$ Czepukojć K.: Zatory płatnicze mogą prowadzić do upadłości, http://www.egospodarka.pl.

${ }^{5}$ Gołaś Z., Bieniasz A.: Zróżnicowanie terminów płatności w wybranych krajach Europy, Zeszyty Naukowe SGGW, Polityki Europejskie, Finanse i Marketing, nr 12(61)/2014.

${ }^{6}$ Dyrektywa Parlamentu Europejskiego i Rady 2011/7/UE z dnia 16 lutego 2011 r. w sprawie zwalczania opóźnień w płatnościach w transakcjach handlowych, www.http://eur-lex.europa.eu/, dostęp: 10.04.2016.

${ }^{7}$ www.atriadus.pl.
} 
Wschodniej $^{8,9}$. W 2015 roku badaniami tymi objęto przedsiębiorstwa sektora B2B w Polsce $^{10}$, Czechach ${ }^{11}$, Słowacji ${ }^{12}$, na Węgrzech ${ }^{13}$ oraz w Turcji1 ${ }^{14}$.

\section{Wyniki badań}

Jednym z wielu źródeł finansowania bieżącej działalności, zwłaszcza w małych i średnich przedsiębiorstwach, jest kredyt kupiecki. Uważany jest on za jedną $\mathrm{z}$ najstarszych form finansowania i ważną alternatywę wobec innych instrumentów oferowanych przez rynek usług finansowych ${ }^{15,16}$. Kredyt kupiecki jest powszechnie stosowaną formą rozliczeń między partnerami biznesowymi umożliwiającą szybszą sprzedaż towarów i usług, jednak udzielany niesprawdzonym odbiorcom może doprowadzić do utraty płynności finansowej. Z danych zawartych w tab.1 wynika, że średnio około $41 \%$ sprzedaży $w$ badanych przedsiębiorstw sektora B2B Europy Wschodniej realizowano przy zastosowaniu kredytu kupieckiego, przy czym ten instrument finansowy chętniej stosowano w transakcjach zagranicznych $(42,9 \%)$ niż krajowych (38,4\%). Jednak skłonność do udzielania kredytu kupieckiego jest w uwzględnionych krajach silnie zróżnicowana. Na Słowacji sprzedaż z odroczonym terminem płatności stanowiła tylko niecałe $20 \%$ wartości sprzedaży i to zarówno w transakcjach krajowych, jak i zagranicznych. Relatywnie niska skłonność, a tym samym konserwatywne podejście do transakcji handlowych cechowała również przedsiębiorstwa w Polsce, gdzie transakcje te stanowiły średnio 28,2\% wartości sprzedaży ogółem oraz 30,7\% wartości sprzedaży krajowej i 25,6\% sprzedaży zagranicznej.

$\mathrm{Z}$ kolei agresywną politykę w tym zakresie stosowały przedsiębiorstwa na Węgrzech. Przeciętnie udział wartości sprzedaży na kredyt w sprzedaży ogółem wynosił w nich aż $72 \%$ i wynikał zarówno z wysokiego poziomu tego wskaźnika dla transakcji zagranicznych (76,6\%), jak i krajowych (67,3\%). W pozostałych krajach (Czechy, Turcja) średni poziom udziału sprzedaży na kredyt kupiecki $(44,8 \%$ i 40,4\%) nie odbiegał istotnie od średniego poziomu charakterystycznego dla Europy Wschodniej. Można jednak zauważyć, że przedsiębiorstwa w Turcji w relatywnie większym stopniu

\footnotetext{
${ }^{8}$ Atriadus Payment Practices Barometer - International survey of B2B payment behavior, survey results for Eastern Europe, May 2015 Spring, www.atriadus.pl.

${ }^{9}$ Statistical appendix Atriadus Payment Practices Barometer, survey results for Eastern Europe, May 2015, www.atriadus.pl.

${ }^{10}$ Atriadus Payment Practices Barometer, International survey of B2B payment behavior, survey results for Poland, May 2015, www.atriadus.pl.

${ }^{11}$ Atriadus Payment Practices Barometer, International survey of B2B payment behavior, survey results for Czech Republic, May 2015, www.atriadus.pl.

${ }_{12}$ Atriadus Payment Practices Barometer, International survey of B2B payment behavior, survey results for Slovakia, May 2015 Spring, www.atriadus.pl.

${ }^{13}$ Atriadus Payment Practices Barometer, International survey of B2B payment behavior, survey results for Hungary, May 2015, www.atriadus.pl.

${ }^{14}$ Atriadus Payment Practices Barometer, International survey of B2B payment behavior, survey results for Turkey, May 2015, www.atriadus.pl.

${ }^{15}$ Nowak D.: Rola i znaczenie kredytu kupieckiego. Zeszyty Naukowe Uniwersytetu Szczecińskiego, Finanse, Rynki Finansowe, Ubezpieczenia, nr 65/2014.

${ }^{16}$ Łuczka T.: Kapitał obcy w małym i średnim przedsiębiorstwie. Wybrane aspekty mikro i akroekonomiczne, PWE, Warszawa - Poznań, 2001, s. 134.
} 
stosowały ten instrument finansowy $\mathrm{w}$ transakcjach zagranicznych (50,3\%), natomiast były mniej skłonne udzielać kredytu kupieckiego w transakcjach krajowych (30,5\%).

Jak wskazują dane zawarte w tab.1 czynnikiem różnicującym skalę stosowania kredytu kupieckiego jest również sektor gospodarki oraz wielkość przedsiębiorstw. Biorąc pod uwagę sektor przetwórstwa przemysłowego można stwierdzić, że udział sprzedaży na kredyt kupiecki jest zbliżony do przeciętnego poziomu tego wskaźnika charakterystycznego dla ogółu badanych przedsiębiorstw, natomiast w handlu hurtowym, detalicznym i dystrybucji oraz sektorze usług zauważalne jest odpowiednio: bardziej agresywne i konserwatywne podejście do transakcji handlowych. W handlu sprzedaż na kredyt kupiecki stanowiła bowiem blisko 50\% wartości sprzedaży, natomiast w usługach tylko $35,5 \%$. Ponadto $\mathrm{w}$ obydwu sektorach przedsiębiorcy mieli większe zaufanie do kontrahentów krajowych (54,8\% i 37,6\%) aniżeli zagranicznych $(44,7 \%$ i $33,4 \%)$. Biorąc z kolei pod uwagę wielkość przedsiębiorstwa można zauważyć, że im większe przedsiębiorstwo tym większa skłonność do sprzedaży z odroczonym terminem płatności. Uzasadnia to postrzeganie mikroprzedsiębiorstw w kontekście konserwatywnej polityki zarządzania należnościami, natomiast duże przedsiębiorstwa w kontekście realizowania bardziej agresywnej polityki zarządzania należnościami.

Tabela 1. Udział sprzedaży na kredyt kupiecki w przedsiębiorstwach sektora B2B w układzie krajów, sektorów gospodarki i wielkości przedsiębiorstw (\%)

\begin{tabular}{cccc}
\hline Wyszczególnienie & $\begin{array}{c}\text { Kontrahenci } \\
\text { krajowi }\end{array}$ & $\begin{array}{c}\text { Kontrahenci } \\
\text { zagraniczni }\end{array}$ & Średnia \\
\hline Ogółem & 42,9 & 38,4 & 40,7 \\
Węgry & 67,3 & 76,6 & 72,0 \\
Polska & 30,7 & 25,6 & 28,2 \\
Słowacja & 19,6 & 19,2 & 19,4 \\
Czechy & 46,8 & 42,8 & 44,8 \\
Turcja & 30,5 & 50,3 & 40,4 \\
Handel hurtowy, detaliczny i dystrybucja & 45,2 & 40,3 & 42,8 \\
Usługi & 54,8 & 44,7 & 49,8 \\
Mikroprzedsiębiorstwa & 37,6 & 33,4 & 35,5 \\
Małe i średnie przedsiębiorstwa & 38,2 & 33,4 & 35,8 \\
Duże przedsiębiorstwa & 46,4 & 39,9 & 43,2 \\
\hline
\end{tabular}

Źródło: Atriadus Payment Practices Barometer, International survey of B2B payment behavior, survey results for Eastern Europe, Poland, Hungary, Slovakia, Czech Republic, Turkey [www.atriadus.pl].

Kolejnym ważnym aspektem problematyki opóźnień płatniczych jest polityka zarządzania należnościami w przedsiębiorstwach i jej efektywność określone przez strukturę czasową należności, terminy płatności oraz skalę zjawiska płatności przeterminowanych i utraconych (tab. 2 i 3). Zarówno w ujęciu ogółem, jak i w przypadku zdecydowanej większości analizowanych krajów, przedsiębiorstwa ustalały termin regulacji kredytu kupieckiego nie dłuższy niż 30 dni. Faktury z takim terminem płatności stanowiły przeciętnie 77,2\% ogółu faktur, a w przedsiębiorstwach B2B na Wegrzech, w Polsce, Słowacji i Czechach ponad 80\% (81,2-86,0\%). Pod tym względem silnie wyróżniają się przedsiębiorstwa $\mathrm{w}$ Turcji. W ich przypadku faktury z krótkim 
terminem płatności (1-30 dni) stanowiły bowiem tylko 53,6\% w następstwie częstszego udzielania kredytu kupieckiego na 31-60 dni (28,6\%), 61-90 dni (11,4\%), a także kredytu powyżej 90 dni $(6,4 \%)$. Konsekwencją takiego kształtu struktury należności zakontraktowanych jest zróżnicowany przeciętny czas zakontraktowanego terminu płatności (tab. 3). Na Węgrzech, w Polsce, Słowacji i Czechach jest on porównywalny oraz relatywnie krótki i wynosi 25-31 dni, natomiast w Turcji relatywnie długi, wiąże się bowiem z 42-dniowym cyklem płatności.

W znacząco większym stopniu różnicuje przedsiębiorstwa B2B analizowanych krajów struktura czasowa należności przeterminowanych, która ponadto wielu przypadkach jest rozbieżna ze strukturą czasową należności zakontraktowanych. W największym natężeniu zjawisko przeterminowanych faktur o 1-30 dni występuje w przedsiębiorstwach słowackich $(68,4 \%)$, w najmniejszym zaś na Węgrzech $(33,3 \%)$. Z kolei przeterminowane faktury od 31 do 60 dni relatywnie częściej dotyczyły przedsiębiorstw wegierskich $(35,9 \%)$ i tureckich $(33,8 \%)$, natomiast rzadziej występowały na Słowacji $(19,7 \%)$ i w Polsce $(20,4 \%)$. Jeszcze inaczej wygląda ta klasyfikacja w przypadku faktur przeterminowanych o 61-90 dni. W tym przypadku największe problemy miały przedsiębiorstwa w Turcji (15,9\%), najmniejsze zaś w Polsce (tylko 5.1\%). W wybranych krajach $\mathrm{w}$ dość dużym natężeniu występuje również zjawisko opóźnień płatniczych przekraczających 90 dni. Przeciętnie, faktury z tak długim opóźnieniem płatności stanowiły 12,5\% ogółu faktur przeterminowanych, jednak na Węgrzech i w Polsce odsetek ten w sektorze B2B wynosił aż około 21\%.

Przedstawione wyżej struktury należności przekładają się na skalę opóźnień płatniczych oraz rzeczywisty czas płatności (tab. 3). W Polsce i Czechach opóźnienie płatności wynosiło 20 dni, a wynik ten był zbieżny z przeciętnym czasem opóźnienia płatności w zbiorowości ogółem. W znacznie mniejszym stopniu opóźnienia płatnicze oddziaływały na gospodarkę finansową w przedsiębiorstwach słowackich (17 dni), a szczególnie na Węgrzech, gdzie regulacja faktur opóźniona była tylko o 10 dni. Na tle przedsiębiorstw wymienionych krajów zdecydowanie najgorzej w tym zakresie wygląda sytuacja w Turcji. Opóźnienie płatności wynosiło w nich bowiem ponad 1 miesiąc (34 dni) i skutkowało 76 dniowym czasem rzeczywistej zapłaty. Jednak trudno uznać, że rzeczywisty czas płatności był w pozostałych krajach krótki. $Z$ danych zawartych $\mathrm{w}$ tab. 3 wynika, że $\mathrm{w}$ przedsiębiorstwach sektora $\mathrm{B} 2 \mathrm{~B} \mathrm{w}$ tych krajach rzeczywisty czas płatności mieścił się na ogół w dość wąskim przedziale 46-51 dni, wskazującym, że faktury regulowano $\mathrm{w}$ nich $\mathrm{w}$ cyklu przekraczającym 1,5 miesiąca. $\mathrm{Na}$ ich tle szczególnie korzystnie wyróżniają się przedsiębiorstwa na Węgrzech, gdzie rzeczywisty czas płatności wynosił przeciętnie 35 dni. Te stan przedsiębiorstw B2B na Wegrzech koresponduje również z korzystną sytuacją wynikającą z relatywnie niskiego odsetka ogółu faktur przeterminowanych $(23,4 \%)$ oraz faktur przeterminowanych powyżej 90 dni $(2,4 \%)$. Można zatem stwierdzić, że mimo największej sprzedaży na kredyt kupiecki (72\%) przedsiębiorstwa węgierskie zarządzają należnościami najbardziej efektywnie. Ich przeciwieństwem są przedsiębiorstwa funkcjonujące w Turcji. Najdłuższemu czasowi opóźnienia płatności i najdłuższemu czasowi rzeczywistemu zapłaty odpowiadały bowiem najwyższy odsetek ogółu faktur przeterminowanych $(52,5 \%)$ oraz najwyższy odsetek faktur przeterminowanych powyżej $90 \mathrm{dni}(14,1 \%)$.

W pozostałych krajach objętych badaniem (Polska, Czechy, Słowacja) problem przeterminowanych faktur występował wprawdzie w mniejszej ale nie marginalnej skali. 
$\mathrm{W}$ tej grupie relatywnie dobrze wygląda sytuacja przedsiębiorstw B2B w Polsce, w których odsetek ogółu faktur przeterminowanych $(23,4 \%)$ oraz faktur przeterminowanych powyżej 90 dni $(2,4 \%)$, był niższy niż przeciętnie. Jednak ten korzystny obraz sytuacji płatniczej w Polsce, a także na Węgrzech, psuje długość zadeklarowanego przez przedsiębiorców cyklu należności przeterminowanych. W Polsce i na Węgrzech cykl ten jest najdłuższy $(80 \mathrm{dni})$ i znacząco przewyższa średnią dla Europy Wschodniej (59 dni). Sytuacja ta może oznaczać, że w przedsiębiorstwach sektora B2B w Polsce i na Węgrzech faktury przeterminowane mają wysoką wartość, znacznie wyższą niż w innych krajach. Ponadto przy dość dobrej ocenie efektywności zarządzania płatnościami węgierskie i polskie firmy nie wyróżniają się pod względem odsetka należności utraconych $(1,0-1,1 \%)$. Pod tym względem najlepiej prezentują się firmy na Słowacji, gdzie odsetek ten wyniósł tylko $0,4 \%$, nagorzej zaś firmy tureckie, w których nieściagalne należności stanowiły $2 \%$ łącznej wartości należności.

Tabela 2. Struktura czasowa zakontraktowanych i przeterminowanych należności przedsiębiorstw sektora B2B w układzie krajów, sektorów gospodarki i wielkości przedsiębiorstw (\%)

\begin{tabular}{ccccc}
\hline Wyszczególnienie & $1-30$ dni & $31-60$ dni & $61-90$ dni & powyżej 90 dni \\
\hline & struktura czasowa należności zakontraktowanych (\%) & \\
Europa Wschodnia & 77,2 & 16,0 & 4,8 & 2,0 \\
Węgry & 86,0 & 13,0 & 1,0 & 0,0 \\
Polska & 83,3 & 13,3 & 2,4 & 1,0 \\
Słowacja & 83,5 & 11,5 & 4,0 & 1,0 \\
Czechy & 81,2 & 12,7 & 4,7 & 1,4 \\
Turcja & 53,6 & 28,6 & 11,4 & 6,4 \\
\hline & struktura czasowa należności przeterminowanych (\%) & 12,5 \\
Europa Wschodnia & 49,7 & 27,9 & 9,9 & 20,5 \\
Węgry & 33,3 & 35,9 & 10,3 & 21,4 \\
Polska & 53,1 & 20,4 & 5,1 & 5,3 \\
Słowacja & 68,4 & 19,7 & 6,6 & 9,9 \\
Czechy & 52,8 & 29,7 & 7,7 & 9,9 \\
Turcja & 40,4 & 33,8 & 15,9 & \\
\hline
\end{tabular}

Źródło: Atriadus Payment Practices Barometer, International survey of B2B payment behavior, survey results for Eastern Europe, Poland, Hungary, Slovakia, Czech Republic, Turkey [www.atriadus.pl].

Tabela 3. Terminy płatności, cykl należności oraz płatności przeterminowane i utracone w sektorze B2B w układzie krajów, sektorów gospodarki i wielkości przedsiębiorstw

\begin{tabular}{|c|c|c|c|c|c|c|}
\hline Wyszczególnienie & Ogółem & Węgry & Polska & Słowacja & Czechy & Turcja \\
\hline $\begin{array}{c}\text { Przeciętny } \\
\text { zakontraktowany termin } \\
\text { płatności (dni) }\end{array}$ & 30 & 25 & 26 & 29 & 31 & 42 \\
\hline $\begin{array}{l}\text { Przeciętny czas opóźnienia } \\
\text { płatności (dni) }\end{array}$ & 20 & 10 & 20 & 17 & 20 & 34 \\
\hline $\begin{array}{l}\text { Rzeczywisty czas płatności } \\
\text { (dni) }\end{array}$ & 50 & 35 & 46 & 46 & 51 & 76 \\
\hline $\begin{array}{c}\text { Wskaźnik cyklu } \\
\text { należności } \\
\text { przeterminowanych (dni) }\end{array}$ & 59 & 80 & 80 & 34 & 50 & 59 \\
\hline
\end{tabular}




\begin{tabular}{|c|c|c|c|c|c|c|}
\hline $\begin{array}{l}\text { Płatności przeterminowane } \\
\text { ogółem (\% ilości) }\end{array}$ & 37,7 & 23,4 & 32,4 & 42,4 & 39,7 & 52,5 \\
\hline $\begin{array}{c}\text { Niezapłacone płatności } \\
\text { przeterminowane } \\
\text { pow. } 90 \text { dni (\% ilości) }\end{array}$ & 7,0 & 2,4 & 5,7 & 3,2 & 6,6 & 14,1 \\
\hline $\begin{array}{c}\text { Należności nieściągalne } \\
\text { (\% wartości) }\end{array}$ & 1,1 & 1,0 & 1,1 & 0,4 & 1,4 & 2,0 \\
\hline
\end{tabular}

Źródło: Atriadus Payment Practices Barometer, International survey of B2B payment behavior, survey results for Eastern Europe, Poland, Hungary, Slovakia, Czech Republic, Turkey [www.atriadus.pl].

Około $60 \%$ i $41 \%$ uwzględnionych w badaniu przedsiębiorstw Europy Wschodniej za najczęstszą przyczynę opóźnionego regulowania płatności krajowych i zagranicznych uznało brak wystarczających środków finansowych, czyli problemy z płynnością kontrahentów. Zdaniem respondentów w Polsce jest to także najczęstsza przyczyna opóźnień $\mathrm{W}$ regulowaniu płatności zagranicznych $(57,6 \%)$ i krajowych (40,5\%) przedsiębiorstw B2B w Polsce. Znacznie silniej problem płynności finansowej kontrahentów podkreślały przedsiębiorstwa na Węgrzech i Słowacji. W ich przypadku ta przyczyna opóźnień płatniczych była wskazywana znacznie częściej i to zarówno w odniesieniu do transakcji krajowych $(78,6 \%$ i $73,5 \%)$, jak i zagranicznych $(64,7 \%$ i $50 \%$ ). Z kolei w wyraźnie mniejszym natężeniu opóźnienia płatnicze były determinowane przez brak płynności w czeskich przedsiębiorstwach B2B. Odsetek wskazań tej przyczyny był w nich najniższy, wynosił bowiem dla transakcji krajowych niecałe $40 \%$, a w obrocie zagranicznym tylko około $24 \%$. Wynik ten jest znacząco niższy niż przeciętnie w przedsiębiorstwach badanych krajów Europy Wschodniej.

Drugą najczęściej wskazywaną przyczyną opóźnionego regulowania płatności jest dość powszechna praktyka traktowania zobowiązań płatniczych jako źródła finansowania działalności bieżącej. $\mathrm{Na}$ tę przyczynę wskazywało przeciętnie 34,7\% respondentów $\mathrm{w}$ odniesieniu do transakcji krajowych i 25,5\% respondentów w odniesieniu do transakcji zagranicznych. Z podobną częstością ta przyczyna była wskazywana przez przedsiębiorstwa B2B w Polsce i Turcji, natomiast w pozostałych krajach oceny te były odmienne. W przypadku Czech traktowanie zobowiązań płatniczych jako źródła finansowania działalności bieżącej jest bowiem, szczególnie w obrocie krajowym (57,8\%), uznawane za najważniejszą przyczynę opóźnień płatniczych, podczas gdy na Węgrzech przyczyna ta miała relatywnie małe znaczenie (10,3-13,6\%).

Formalna niewypłacalność kontrahentów w transakcjach krajowych jest z kolei przyczyną opóźnień płatniczych, na którą przeciętnie wskazywało $24,2 \%$ przedsiębiorców. Generalnie ocena wpływu tego czynnika wśród przedsiębiorców sektora B2B analizowanych krajów była zbieżna, poza przedsiębiorcami z Czech. W ich przypadku odsetek wskazań na tę przyczynę wydłużania cyklu płatności był znacząco wyższy i w odniesieniu do transakcji krajowych przekraczał $42 \%$, podczas gdy w pozostałych krajach wynosił 16-26\%. Zauważyć można ponadto, że ryzyko opóźnień płatniczych $\mathrm{z}$ tytułu niewypłacalności kontrahentów jest wyraźnie mniejsze w transakcjach zagranicznych. Przeciętnie bowiem wskazywało na nie około 15\% respondentów, a na Węgrzech i Słowacji tylko 4-7\%.

Z punktu widzenia przedsiębiorstw sektora B2B ważnym czynnikiem wpływającym na opóźnienia płatnicze są również złożone procedury płatności, głównie w handlu zagranicznym (24\%). Na ten czynnik wskazywały przede wszystkim 
przedsiębiorstwa w Czechach (35\%) oraz w Turcji (28\%), nie mniej analizując dane zawarte w tab. 4 można zauważyć, że opinie w tym zakresie są dość zróżnicowane. Przykładowo, na Węgrzech problem procedur płatniczych w transakcjach zagranicznych nie jest często wskazywany (16\%) ale w transakcjach krajowych uznawany jest za bardzo ważny czynnik opóźnień płatniczych, wskazało go bowiem aż ponad $90 \%$ przedsiębiorców. $Z$ kolei biorąc pod uwagę przedsiębiorstwa B2B na Słowacji, zauważyć można, że $\mathrm{w}$ opinii przedsiębiorców $\mathrm{z}$ tego kraju procedury płatnicze $\mathrm{w}$ marginalnym stopniu wpływają na wydłużanie cyklu zobowiązań. Zarówno w odniesieniu do transakcji krajowych $(6,8 \%)$, jak i zagranicznych $(3,6 \%)$ na tę przyczynę wskazywało relatywnie bardzo mało przedsiębiorstw.

Pozostałe przyczyny opóźnienia płatności były wskazywane ze znacznie mniejszą częstością. Wśród nich można jedynie wskazać na relatywnie większe negatywne oddziaływanie nieefektywności systemu bankowego w krajowych i zagranicznych transakcjach handlowych charakterystyczną dla Turcji $(25,9 \%$ i $36,6 \%)$, spory o jakość towarów i usług w transakcjach zagranicznych w Czechach $(33,3 \%)$, błędy na fakturach $w$ transakcjach zagranicznych wskazywane przez polskich $(21,4 \%) \mathrm{i}$ tureckich $(20,4 \%)$ przedsiębiorców oraz niezgodność towarów lub usług $\mathrm{z}$ treścią zagranicznych umów handlowych w Turcji (18,3\%).

Generalnie dość podobnie wygląda ranking przyczyn opóźnień płatniczych postrzeganych $\mathrm{w}$ perspektywie sektorowej oraz wielkości przedsiębiorstw, przy czym podobnie jak w układzie krajów pewne różnice są zauważalne, w tym szczególnie przy uwzględnieniu typu geograficznego zawieranych transakcji (tab. 5). Biorąc pod uwagę sektory gospodarki można zauważyć, że najczęściej wymieniana przyczyna opóźnień płatniczych, jaką jest niewystarczająca dostępność środków finansowych, wskazywana jest generalnie z podobną i największą częstością w trzech rozpatrywanych sektorach, a niewielkie różnice zauważalne są jedynie w odniesieniu do handlu hurtowego, detalicznego i dystrybucji. W przypadku tego sektora gospodarki można mówić o relatywnie silniejszym oddziaływaniu analizowanej przyczyny $w$ transakcjach krajowych, wskazywało na nią bowiem ponad $64 \%$ przedsiębiorstw. Ponadto, podobnie jak w układzie krajów, problemy $\mathrm{z}$ dostępnością środków finansowych były $\mathrm{w}$ rozpatrywanych sektorach $\mathrm{w}$ przypadku transakcji zagranicznych $(41,1-41,7 \%)$ wskazywane znacznie rzadziej niż w transakcjach krajowych $(58,8-64,1 \%)$.

$\mathrm{Na}$ finansowanie działalności bieżącej długiem, jako przyczynę opóźnień płatniczych, wskazywał dość podobny odsetek przedsiębiorców z poszczególnych sektorów gospodarki, a o relatywnie silniejszym oddziaływaniu tej przyczyny na terminy płatności można mówić tylko $\mathrm{w}$ odniesieniu do transakcji zagranicznych w przetwórstwie przemysłowym. W tym sektorze i w odniesieniu do handlu zagranicznego ponad $30 \%$ przedsiębiorców wskazywało na tę przyczynę, podczas gdy w pozostałych sektorach około $22 \%$.

Trzecia najcześciej wymienia przyczyna opóźnień płatniczych - formalna niewypłacalność kupującego - w bardzo niskim stopniu różnicuje wyniki w układzie sektorowym. Wyniki zawarte w tab. 5 wskazują bowiem, że zarówno w transakcjach krajowych (23,7-25,6\%), jak i zagranicznych (13,5-16,7\%), częstość wskazań jest generalnie bardzo podobna. Również złożone procedury płatnicze $\mathrm{w}$ transakcjach zagranicznych są dość często wymieniane jako istotne przyczyny opóźnień regulowania faktur. Na tę przyczynę wskazuje bowiem ponad $20 \%$ przedsiębiorców, w tym 
szczególnie z sektora usług, w którym ten odsetek przekraczał 30\%. W podobnym natężeniu i także w odniesieniu do faktur zagranicznych upatruje się przyczyn opóźnień płatniczych $\mathrm{w}$ nieefektywności systemu bankowego. W tym przypadku częstość wskazań była w analizowanych sektorach dość podobna (około $20 \%$ przedsiębiorstw).

Pozostałe przyczyny opóźnienia płatności w układzie sektorowym były wskazywane z mniejszą częstością. Wśród nich można jedynie wskazać na relatywnie większe negatywne oddziaływanie na terminy płatności takich czynników jak: spory o jakość towarów i usług w transakcjach zagranicznych w sektorze handlu $(19,4 \%)$ i usług $(20,4 \%)$, błędy na fakturach $\mathrm{w}$ transakcjach zagranicznych w sektorze usług $(17,4 \%)$, oraz wysłanie faktury zagranicznej do niewłaściwej osoby $(19,7 \%)$, dotyczące również sektora usług.

W układzie wielkości przedsiębiorstw ranking przyczyn opóźnień płatniczych jest praktycznie taki sam jak w przypadku badanych krajów i sektorów gospodarki. Zauważyć jednak można, że wielkość przedsiębiorstwa w powiązaniu z typem transakcji różnokierunkowo różnicuje częstość wskazywania przyczyn. W przypadku najczęściej wymienianych przyczyn, tj. niewystarczającej dostępności środków finansowych oraz finansowania długiem działalności bieżącej, wraz ze wzrostem wielkości przedsiębiorstwa częstość wskazań dla transakcji krajowych maleje, natomiast w transakcjach zagranicznych rośnie. Inaczej wygląda sytuacja w tym zakresie jeżeli weźmie się pod uwagę niewypłacalność kontrahenta oraz nieefektywność systemu bankowego. W obydwu bowiem typach transakcji odsetek wskazań na te przyczyny opóźnień płatniczych rośnie, przy czym jest on znacząco wyższy w transakcjach krajowych niż zagranicznych. Z kolei skomplikowane procedury płatności faktur zagranicznych są tą przyczyną opóźnień płatności, która w zbliżonym, ale również $\mathrm{w}$ większym stopniu niż w przypadku faktur krajowych, wskazywana jest z podobną częstością we wszystkich klasach wielkości przedsiębiorstw (19,5-25,0\%).

Pozostałe przyczyny opóźnień płatności w układzie wielkości przedsiębiorstw wskazywane były z relatywnie mniejszą częstością. Nie mniej można zauważyć, że na ogół im większe przedsiębiorstwo tym częściej te przyczyny dotyczyły faktur zagranicznych. Dotyczy to przede wszystkim sporów o jakość towarów i usług, błędnych informacji na fakturach oraz wysyłania faktur do niewłaściwej osoby.

Tabela 4. Przyczyny opóźnienia płatności w sektorze przedsiębiorstw B2B w układzie krajów (\%)

\begin{tabular}{cccccccc}
\hline $\begin{array}{c}\text { Przyczyny opóźnień } \\
\text { płatniczych }\end{array}$ & & Ogółem & Polska & Czechy & Węgry & Słowacja & Turcja \\
\hline Niewystarczająca & 1 & 59,98 & 57,61 & 39,20 & 78,57 & 73,46 & 57,51 \\
dostępność środków & 2 & 41,45 & 40,48 & 23,61 & 64,71 & 50,00 & 36,56 \\
Traktowanie zaległych & 1 & 34,75 & 36,96 & 57,79 & 13,64 & 26,54 & 32,64 \\
długów jako źródło & 2 & 25,51 & 29,76 & 34,72 & 10,29 & 35,71 & 22,58 \\
finansowania & 1 & 24,22 & 26,09 & 42,21 & 15,58 & 17,28 & 16,58 \\
Formalna niewypłacalność & 2 & 15,36 & 20,24 & 19,44 & 4,41 & 7,14 & 18,28 \\
kupującego & 1 & 13,34 & 15,22 & 13,07 & 90,09 & 6,76 & 20,73 \\
& 2 & 24,06 & 23,81 & 34,72 & 16,18 & 3,57 & 27,96 \\
Złożone procedury płatności & 1 & 11,43 & 12,50 & 8,54 & 3,25 & 4,32 & 25,91 \\
Nieefektywność & 2 & 20,87 & 19,05 & 22,20 & 2,94 & 14,29 & 36,56 \\
systemu bankowego & 1 & 8,97 & 12,50 & 15,08 & 0,65 & 3,70 & 10,36
\end{tabular}




\begin{tabular}{cccccccc} 
towarów lub usług & 2 & 17,68 & 20,24 & 33,33 & 2,94 & 10,71 & 16,13 \\
Błędne informacje & 1 & 8,07 & 10,33 & 9,55 & 2,60 & 4,94 & 11,40 \\
na fakturze & 2 & 14,78 & 21,43 & 8,33 & 5,88 & 14,29 & 20,43 \\
Towary lub usługi & 1 & 6,05 & 10,33 & 5,53 & 0,65 & 1,23 & 10,88 \\
niezgodne z treścią umów & 2 & 8,41 & 8,33 & 4,17 & 1,47 & 3,57 & 18,28 \\
Wysłanie faktury do & 1 & 5,38 & 4,89 & 4,52 & 4,55 & 5,56 & 7,25 \\
niewłaściwej osoby & 2 & 12,46 & 16,67 & 16,67 & 7,35 & 3,57 & 11,83 \\
& 1 & 5,49 & 3,26 & 7,54 & 3,25 & 11,73 & 2,07 \\
Inne & 2 & 3,19 & 0,00 & 1,39 & 1,47 & 25,00 & 2,15 \\
\hline
\end{tabular}

${ }^{1} 1-\mathrm{w}$ transakcjach krajowych, $2-\mathrm{w}$ transakcjach zagranicznych

Źródło: Atriadus Payment Practices Barometer, International survey of B2B payment behavior, survey results for Eastern Europe, Poland, Hungary, Slovakia, Czech Republic, Turkey [www.atriadus.pl].

Tabela 5. Przyczyny opóźnienia płatności w sektorze przedsiębiorstw B2B w układzie sektorów gospodarki i wielkości przedsiębiorstw (\%)

\begin{tabular}{|c|c|c|c|c|c|c|c|}
\hline \multirow[b]{2}{*}{$\begin{array}{l}\text { Przyczyny opóźnień } \\
\text { płatniczych }\end{array}$} & & \multicolumn{3}{|c|}{ Sektory przedsiębiorstw } & \multicolumn{3}{|c|}{ Wielkość przedsiębiorstw } \\
\hline & & $\begin{array}{l}\text { Przetwórstwo } \\
\text { przemysłowe }\end{array}$ & $\begin{array}{c}\text { Handel } \\
\text { hurtowy, } \\
\text { detaliczny i } \\
\text { dystrybucja }\end{array}$ & Usługi & Mikro & $\begin{array}{c}\text { Małe } \\
\text { i } \\
\text { średnie }\end{array}$ & Duże \\
\hline \multirow{2}{*}{$\begin{array}{l}\text { Niewystarczająca } \\
\text { dostępność środków }\end{array}$} & 1 & 58,82 & 64,10 & 59,77 & 61,56 & 60,00 & 50,75 \\
\hline & 2 & 41,13 & 41,67 & 41,67 & 39,71 & 40,68 & 48,78 \\
\hline \multirow{4}{*}{$\begin{array}{l}\text { Traktowanie zaległych } \\
\text { długów jako źródło } \\
\text { finansowania } \\
\text { Formalna } \\
\text { niewypłacalność } \\
\text { kupującego }\end{array}$} & 1 & 36,30 & 32,05 & 34,76 & 36,62 & 34,09 & 28,36 \\
\hline & 2 & 30,50 & 22,22 & 21,97 & 20,59 & 26,69 & 26,83 \\
\hline & 1 & 25,56 & 23,72 & 23,61 & 22,08 & 25,23 & 29,85 \\
\hline & 2 & 13,48 & 16,67 & 16,67 & 8,82 & 16,95 & 17,07 \\
\hline \multirow{2}{*}{$\begin{array}{c}\text { Złożone procedury } \\
\text { płatności }\end{array}$} & 1 & 12,22 & 11,54 & 14,59 & 11,95 & 14,77 & 11,94 \\
\hline & 2 & 19,86 & 20,83 & 30,30 & 23,53 & 25,00 & 19,51 \\
\hline \multirow{2}{*}{$\begin{array}{c}\text { Nieefektywność } \\
\text { systemu bankowego }\end{array}$} & 1 & 11,85 & 8,33 & 12,23 & 9,87 & 11,82 & 17,91 \\
\hline & 2 & 19,15 & 20,83 & 22,73 & 17,65 & 20,76 & 26,83 \\
\hline \multirow{2}{*}{$\begin{array}{l}\text { Spory o jakość } \\
\text { towarów lub usług }\end{array}$} & 1 & 12,59 & 7,69 & 7,30 & 6,49 & 9,77 & 17,91 \\
\hline & 2 & 14,18 & 19,44 & 20,45 & 11,76 & 19,92 & 14,63 \\
\hline \multirow{2}{*}{$\begin{array}{l}\text { Błędne informacje } \\
\text { na fakturze }\end{array}$} & 1 & 7,78 & 4,49 & 9,44 & 5,45 & 9,55 & 13,43 \\
\hline & 2 & 14,18 & 11,11 & 17,42 & 5,88 & 15,25 & 26,83 \\
\hline \multirow{2}{*}{$\begin{array}{l}\text { Towary lub usługi } \\
\text { niezgodne z treścią umów }\end{array}$} & 1 & 6,30 & 3,21 & 6,87 & 4,16 & 6,36 & 14,93 \\
\hline & 2 & 7,09 & 8,33 & 9,85 & 7,35 & 8,05 & 12,20 \\
\hline \multirow{2}{*}{$\begin{array}{l}\text { Wysłanie faktury do } \\
\text { niewłaściwej osoby }\end{array}$} & 1 & 3,70 & 5,13 & 6,44 & 4,42 & 6,14 & 5,97 \\
\hline & 2 & 9,22 & 5,56 & 19,70 & 8,82 & 13,56 & 12,20 \\
\hline \multirow{2}{*}{ Inne } & 1 & 5,93 & 7,05 & 4,72 & 8,31 & 3,18 & 4,48 \\
\hline & 2 & 3,55 & 4,17 & 2,27 & 5,88 & 2,12 & 4,88 \\
\hline
\end{tabular}

${ }^{1} 1-\mathrm{w}$ transakcjach krajowych, 2 - w transakcjach zagranicznych

Źródło: Atriadus Payment Practices Barometer, International survey of B2B payment behavior, survey results for Eastern Europe, Poland, Hungary, Slovakia, Czech Republic, Turkey [www.atriadus.pl]. 


\section{Podsumowanie}

Opóźnienia terminów płatności w transakcjach handlowych stanowią poważne zagrożenie dla stabilności prowadzenia działalności gospodarczej, skutkują bowiem narastaniem problemów związanych z utrzymaniem płynności finansowej, generują dodatkowe koszty, redukują zyski oraz bardzo często prowadzą do utraty wiarygodności kredytowej a nawet bankructwa. Przeprowadzone w artykule analizy uzasadniają sformułowanie następujących uwag końcowych:

- Mimo wprowadzenia na szczeblu unijnym i narodowym regulacji prawnych dotyczących terminów zapłaty w transakcjach handlowych, problem opóźnień płatniczych występuje nadal w dużej skali, i tym samym wskazuje na słabą skuteczność opracowanych instrumentów.

- Średnio około 41\% sprzedaży w badanych przedsiębiorstw sektora B2B Europy Wschodniej realizowano przy zastosowaniu kredytu kupieckiego, przy czym ten instrument finansowy chętniej stosowano w transakcjach zagranicznych niż krajowych. Skłonność do udzielania kredytu kupieckiego jest w uwzględnionych krajach silnie zróżnicowana. Na Słowacji i w Polsce sprzedaż z odroczonym terminem płatności stanowiła tylko 20-30\% wartości sprzedaży, podczas gdy na Węgrzech aż około $70 \%$.

- Struktura terminowa należności zakontraktowanych w przedsiębiorstwach sektora B2B porównywanych krajów Europy Wschodniej jest, poza Turcją, bardzo podobna. Kontrakty zawierano bowiem głównie na termin do 30 dni (ponad 80\%), poza Turcją gdzie należności zakontraktowane w tym przedziale czasowym stanowiły około $54 \%$ umów $\mathrm{z}$ odroczonym terminem płatności. $Z$ kolei zasadnicze różnice stwierdzono w przypadku struktury należności przeterminowanych. Wprawdzie dominowały w nich głównie faktury płatne do 30 dni (około 50\%), jednak nie mały udział miały również faktury przeterminowane $\mathrm{z}$ dłuższymi terminami płatności. W Polsce i na Węgrzech faktury przeterminowane powyżej 90 dni stanowiły w przedsiębiorstwach sektora B2B aż ponad $20 \%$ faktur przeterminowanych ogółem.

- Dysproporcje między strukturą należności zakontraktowanych i przeterminowanych przekładają się na skalę opóźnień płatniczych oraz rzeczywisty czas płatności. W najmniejszym stopniu opóźnienia płatnicze oddziaływały na gospodarkę finansową przedsiębiorstw słowackich $(17 \mathrm{dni})$ i węgierskich, gdzie regulacja faktur opóźniona była tylko o $10 \mathrm{dni}$. Na ich tle zdecydowanie najgorzej wygląda sytuacja $\mathrm{w}$ Turcji, gdzie opóźnienie płatności wynosiło średnio ponad 1 miesiąc i skutkowało 76 dniowym czasem rzeczywistej zapłaty. Jednak rzeczywisty czas płatności nie był w pozostałych krajach krótki, mieścił się na ogół w dość wąskim przedziale 46-51 dni. Generalnie jednak najkorzystniej wyróżniały się przedsiębiorstwa na Węgrzech, gdzie rzeczywisty czas płatności wynosił przeciętnie 35 dni.

- Główne przyczyny opóźnień płatniczych przedsiębiorcy z sektora B2B upatrują w ograniczonym dostępie kontrahentów do środków finansowych, w nagminnej praktyce traktowania zaległych zobowiązań jako źródła finansowania bieżącej działalności, formalnej niewypłacalności kontrahentów oraz w złożonych procedurach płatności. Na ogół te przyczyny były przez przedsiębiorców B2B najczęściej wymieniane, przy czym częstość ta była w wybranych przekrojach (kraj, sektor gospodarki, wielkość przedsiębiorstwa) silniej powiązana $\mathrm{z}$ krajowymi lub zagranicznymi transakcjami handlowymi. 


\section{Literatura}

Atriadus Payment Practices Barometer - International survey of B2B payment behavior, survey results for Eastern Europe, May 2015 Spring, www.atriadus.pl, dostęp: 16.04.2016.

Atriadus Payment Practices Barometer, International survey of B2B payment behavior, survey results for Poland, May 2015, www.atriadus.pl, dostęp: 16.04.2016.

Atriadus Payment Practices Barometer, International survey of B2B payment behavior, survey results for Czech Republic, May 2015, www.atriadus.pl, dostęp: 16.04.2016.

Atriadus Payment Practices Barometer, International survey of B2B payment behavior, survey results for Slovakia, May 2015 Spring, www.atriadus.pl, dostęp: 16.04.2016.

Atriadus Payment Practices Barometer, International survey of B2B payment behavior, survey results for Hungary, May 2015, www.atriadus.pl, dostęp: 16.04.2016.

Atriadus Payment Practices Barometer, International survey of B2B payment behavior, survey results for Turkey, May 2015, www.atriadus.pl, dostęp: 16.04.2016.

Cicirko T.: Możliwości ograniczania zatorów płatniczych poprzez system podatkowy. Zeszyty Naukowe Politechniki Rzeszowskiej, Zarządzanie i Marketing, nr 272(17)/2010.

Czepukojć K.: Zatory płatnicze mogą prowadzić do upadłości, http://www.egospodarka.pl, dostęp: 10.04.2016.

Dyrektywa Parlamentu Europejskiego i Rady 2011/7/UE z dnia 16 lutego 2011 r. w sprawie zwalczania opóźnień w płatnościach w transakcjach handlowych.

European Payment Report 2015, www.intrum.com, dostęp: 20.04.2016.

Gołaś J.: Prawne i ekonomiczne uwarunkowania opóźnień płatniczych w transakcjach handlowych przedsiębiorstw w Polsce, Ekonomika i Organizacja Przedsiębiorstw, nr 2/2016.

Gołaś Z., Bieniasz A.: Zróżnicowanie terminów płatności w wybranych krajach Europy, Zeszyty Naukowe SGGW, Polityki Europejskie, Finanse i Marketing, nr 12(61)/2014.

Nowak D.: Rola i znaczenie kredytu kupieckiego. Zeszyty Naukowe Uniwersytetu Szczecińskiego, Finanse, Rynki Finansowe, Ubezpieczenia, nr 65/2014.

Łuczka T.: Kapitał obcy w małym i średnim przedsiębiorstwie. Wybrane aspekty mikro i makroekonomiczne, PWE, Warszawa - Poznań, 2001.

Statistical appendix Atriadus Payment Practices Barometer, survey results for Eastern Europe, May 2015, www.atriadus.pl, dostep: 16.04.2016.

www.atriadus.pl - strona internetowa firmy Atriadus, dostęp: 16.04.2016.

\section{Summary}

The article presents results of multi-faceted analysis of differentiation of payments delays in commercial transactions of B2B sector enterprises located in chosen eastern Europe countries. The analysis was based on data coming from reports of the international business information agency Atriadus regarding enterprises in Poland, Slovakia, Czech Republic, Hungary and Turkey. The research proved that average of approx. $41 \%$ of sales in surveyed B2B sector enterprises were carried with use of the trade credit, mostly in foreign transactions. The research also proved that most contracts were concluded for payment period of 30 days (over $80 \%$ ), with exception of Turkey where contracted liabilities equaled to approx. 54\% of all contracts. Furthermore, it was proved that the smallest payments delay rate was observed in case of enterprises located in Slovakia and Hungary (10-17 days), whereas the biggest delay rate was observed in case of Turkey (76 days). According to the research, contractors' limited access to financial resources, practice of treating outstanding debts as financial sources for current operations, formal insolvency of contractors and complex payments procedures should be considered as four main causes of payment delays in the B2B sector enterprises.

Key words: payment delays, B2B sector, Eastern Europe 
Informacja o autorze:

dr hab. Zbigniew Gołaś

Wydział Ekonomiczno-Społeczny

Katedra Ekonomiki Przedsiębiorstw Agrobiznesu

Uniwersytet Przyrodniczy w Poznaniu

ul. Wojska Polskiego 28

60-637 Poznań

e-mail: zbyszekg@up.poznan.pl 